\title{
Kesenian Barongan Kabupaten Pati dalam Pergeseran Budaya
}

\author{
Laura Andri Retno M \\ Fakultas Ilmu Budaya Universitas Diponegoro \\ Email: lauraandrirm@yahoo.co.id
}

\begin{abstract}
Traditional arts are used to express the beauty of the human soul. In traditional artwork implicit message of the society of knowledge, ideas, beliefs and values norms. One example of a traditional art that has the function of rituals is Barongan. Barongan is a community-owned art Kabupaten Pati, Jawa Tengah raised to preserve the culture and values in society. Through a qualitative descriptive approach with observation techniques and literature, it was found that at the next stage of development, especially in the modern society, arts performances Barongan shift function just as more entertainment. Barongan existence as art and traditional culture in Indonesia progressively eroded by the expansion of global art and culture. Therefore, efforts must be made to preserve the arts and culture in the midst of changing times and foreign cultural influences have been increasing in Indonesia.
\end{abstract}

Keywords : traditional art, modernization, a cultural shift, cultural preservation

\section{Intisari}

Kesenian tradisional digunakan untuk mengekspresikan rasa keindahan dari dalam jiwa manusia. Dalam karya seni tradisional tersirat pesan dari masyarakatnya berupa pengetahuan, gagasan, kepercayaan dan nilai norma. Salah satu contoh kesenian tradisional yang memiliki fungsi ritual adalah Barongan. Barongan merupakan kesenian yang dimiliki masyarakat Kabupaten Pati Jawa Tengah yang dimunculkan untuk melestarikan budaya dan nilai-nilai dalam masyarakatnya. Melalui pendekatan deskritif kualitatif dengan teknik observasi dan kepustakaan, ditemukan bahwa pada tahap perkembangan berikutnya, terutama pada masyarakat modern, pementasan kesenian Barongan bergeser fungsinya hanya sekedar sebagai hiburan semata. Eksistensi Barongan sebagai seni dan budaya tradisional di Indonesia semakin lama semakin tergerus oleh ekspansi seni dan budaya global. Oleh karena itu, berbagai upaya harus dilakukan untuk melestarikan seni dan budaya daerah di tengah-tengah perubahan zaman dan pengaruh budaya asing yang semakin gencar di Indonesia.

Kata kunci : kesenian tradisional, modernisasi, pergeseran budaya, pelestarian budaya.

\section{Pendahuluan}

Masyarakat umumnya memahami kebudayaan sebagai suatu hal yang mencakup pengetahuan, kepercayaan, kesenian, moral, adat istiadat, kebiasaan serta kemampuan yang didapatkan mereka dalam berinteraksi dengan orang lain. Di kehidupan seharihari, kebudayaan dapat juga diartikan sebagai peninggalan sejarah yang bersifat tradisional seperti tarian daerah, alat musik daerah, senjata tradisional, bahasa daerah, 
dan lain sebagainya. Kesenian tradisional sebagai bagian dari budaya tradisional merupakan sarana yang digunakan untuk mengekspresikan rasa keindahan dari dalam jiwa manusia. Suatu hasil ekspresi manusia akan keindahan dengan latar belakang tradisi atau sistem budaya masyarakat pemilik kesenian. Karya seni tradisional menyiratkan pesan dari masyarakatnya berupa pengetahuan, gagasan, kepercayaan, nilai serta norma.

Ritual merupakan salah satu fungsi dalam kesenian tradisional selain tuntunan dan hiburan. Dalam fungsi ritual, seni yang dimunculkan biasanya dianalogikan pada suatu gerak, suara, ataupun tindakan-tindakan tertentu sebagai ungkapan atau simbol untuk berkomunikasi. Tidak mengherankan jika bentuknya masih sangat sederhana, baik dari aspek musik iringan, busana (kostum) serta rias, gerak, maupun penggunaan dekorasi sebagai setting pertunjukan. Sebelum masa kemerdekaan, masyarakat terutama daerah pedesaan memfungsikan kesenian tradisional sebagai kegiatan ritual. Demi untuk mempertahankan dan meningkatkan taraf hidup, mereka merasa perlu memenuhi berbagai kebutuhan yang berlaku secara universal. Kesenian merupakan kebutuhan integritas untuk meningkatkan dan melangsungkan taraf hidup. Masyarakat petani pedesaan (peasant society) Jawa yang tergolong dalam peringkat hidup subsistens misalnya, telah lama mengembangkan kesenian sebagai suatu kebutuhan integrif dan secara fungsional berkaitan dengan kebudayaan yang berlaku pada masyarakat tersebut.(Koentjaraningrat, 1994: 211-220).

Pada masa sekarang ini, masih kita jumpai jejak-jejak seni yang berperan sebagai media ritual atau pemujaan, misalnya kesenian Barongan di kabupaten Pati. Kesenian ini masih bertahan hidup meski dalam perkembangannya mengalami pasang surut. Barongan merupakan kesenian yang bisa dijumpai di daerah pesisir Jawa tengah seperti Tegal, Demak, Kudus, Pati, Purwodadi, Blora, dan sekitarnya meskipun dengan nama/istilah yang berbeda. Di kabupaten Pati sendiri terdapat 33 kesenian dan 11 budaya tradisi, salah satu di antaranya adalah kesenian Barongan. Ada beberapa kelompok seni Barongan yang tersebar di Kabupaten Pati, seperti Paguyuban Seni Barongan Cipto Budoyo Desa Sarirejo Kemiri, Kelompok Seni Barongan Jogo Rogo Desa Gabus, Barongan Seni Budoyo Desa Sinoman, Barongan Wahyu Arom Joyo, dan sebagainya. Kesenian tradisional Barongan sering dipentaskan oleh warga masyarakat Pati untuk keperluan ritual yang dilaksanakan setiap tahun pada bulan Sura. Kesenian Barongan juga sering dipentaskan dalam acara pernikahan dan acara khitanan. 
Pertunjukan kesenian Barongan dalam upacara ritual pada bulan Sura memiliki struktur dan fungsi yang berbeda dengan pertunjukan dalam acara hiburan atau pernikahan. Sayangnya, saat ini animo serta minat masyarakat terhadap kesenian Barongan tersebut semakin menipis.

Perhatian masyarakat Pati terhadap kesenian Barongan yang mulai berkurang mengakibatkan perkembangan kesenian tersebut mengalami pasang surut. Banyak kelompok seni yang mengalami kondisi sepi tanggapan, lalu pelan-pelan menghilang. Ada pula yang sempat mati suri dan selang beberapa waktu muncul kembali berkat totalitas dari masing-masing anggota kelompok kesenian Barongan tersebut. Para anggota tidak segan bekerja untuk menghidupi paguyuban kesenian mereka atas dasar komitmen dan rasa kecintaan yang besar. Modernisasi telah menggeser fungsi-fungsi awal dari kesenian tradisional, khususnya kesenian Barongan. Masuknya budaya asing ke Indonesia berbenturan dengan budaya tradisional yang bersifat lokal sehingga fungsi kesenian tradisional mengalami pergeseran. Proses sekularisasi dan komersialisasi yang menghebat pada abad XX memberikan dampak negatif bagi kesenian tradisional. Fungsi ritual, pendidikan serta penggambaran identitas bangsa bergeser menjadi kegiatan komersial yang bersifat hiburan belaka. Meskipun dalam kesenian Barongan fungsi ritualnya masih melekat namun kadarnya menyusut tergantung kebutuhan masyarakat setempat.

Penelitian ini menggunakan pendekatan deskriptif kualitatif, dengan tujuan untuk menggambarkan dan menjelaskan suatu keadaan sebagaimana adanya. Lokasi penelitian adalah tempat-tempat kelompok seni Barongan di Kabupaten Pati. Pengumpulan data penelitian menggunakan metode observasi, wawancara dan studi pustaka. Observasi dilakukan dengan pengamatan langsung dan terencana terhadap kesenian Barongan untuk memperoleh gambaran yang tepat tentang peran kesenian tersebut dalam masyarakat serta sejauh mana masyarakat memfungsikan kesenian tradisional tersebut dalam keseharian mereka. Wawancara yang dilakukan secara langsung kepada para informan yaitu ketua paguyuban dan beberapa masyarakat sebagai penikmat kesenian. Dokumentasi dilakukan dengan cara menelaah bahan dokumen tentang kesenian Barongan. Adapun dokumen yang diperoleh di lapangan di antaranya adalah artikel dan berita media massa. Adapun langkah-langkah analisis merujuk dari Miles dan Huberman (1994), yakni melalui proses reduksi data, sajian data dan penarikan simpulan. 


\section{Pembahasan}

\section{Sejarah dan Bentuk Kesenian Barongan}

Barongan berasal dari kata "Barong", yaitu singo barong, seekor singa besar yang menakutkan. Bentuk yang menyerupai singo barong biasanya dimainkan oleh 2 (dua) orang, seorang berperan menjadi kepala dan seorang lagi berperan memainkan bagian ekor. Sedangkan badannya terbuat dari "kadut/bagor", semacam serat atau rami dihias dengan warna menyerupai singa. Pengertian Barongan dalam kesenian tersebut adalah perlengkapan yang dibuat untuk menggambarkan seekor singo barong atau singa besar yang buas, dimainkan oleh 2 (dua) orang pemain. Keduanya bergerak serasi dan terpadu saling berkaitan. Bagian ekor menurut dan mengikuti gerak pemain yang berperan menjadi kepala singa atau barongan (Sepiolita, 2014: 277).

Kesenian Barongan berbentuk tarian kelompok, yang menirukan keperkasaan gerak seekor Singa Raksasa. Peranan singo barong secara totalitas di dalam penyajian dikarenakan peran tokoh tersebut sangat dominan, di samping ada beberapa tokoh yang tidak dapat dipisahkan yaitu: Bujangganong/Pujonggo Anom Joko Lodro/Gendruwo Pasukan berkuda/reog Noyontoko Untub. Selain tokoh tersebut di atas pementasan kesenian Barongan juga dilengkapi beberapa perlengkapan yang berfungsi sebagai instrumen musik antara lain: Kendang, Gedhuk, Bonang, Saron, Demung dan Kempul. Masuknya budaya asing dalam kehidupan masyarakat Pati mempengaruhi bentuk kesenian Barongan ini. Hal itu ditandai dengan digunakannya beberapa alat musik modern untuk penambahan instrumen berupa Drum, Terompet, Kendang besar dan Keyboards. Kesenian barongan bersumber dari hikayat Panji, yaitu suatu cerita yang diawali dari iring-iringan prajurit berkuda mengawal Raden Panji Asmarabangun/Pujonggo Anom dan Singo Barong. Tokoh Singo Barong (singa raksasa) yang merupakan tokoh utama dalam kesenian barongan, merupakan visualisasi dari semangat para pejuang itu.

Barongan merupakan salah satu kesenian tradisional Pati yang diwariskan secara turun temurun oleh nenek moyang. Seiring perkembangan zaman, kesenian tradisional ini mengalami penurunan minat dan eksistensi. Realitas itu setidak-tidaknya bisa dilihat dari penyajian arak-arakan Barongan yang berbeda dari masa lalu dengan masa sekarang. Pada masa lalu, kelompok kesenian Barongan sering dipertunjukkan. 
Masyarakat Pati masih sangat antusias datang setiap kali ada pertunjukan kesenian tersebut. Hampir seluruh desa memiliki kelompok seni Barongan. Pertunjukan kesenian ini seolah sudah menjadi tradisi dalam kehidupan masyarakatnya, hal ini dapat dilihat dari peristiwa penting dalam kehidupan masyarakat yang selalu melibatkan kesenian Barongan. Pada upacara bersih desa (sedekah bumi) yang dilakukan setiap bulan Sura, masyarakat Pati melakukan upacara ritual di desa masing-masing dengan menggunakan kesenian Barongan untuk memperoleh keselamatan dan terhindar dari bahaya ataupun roh-roh jahat. Selain itu, sering pula kesenian Barongan digunakan pada upacara ruwatan. Masyarakat memfungsikan kesenian tersebut sebagai tolak bala supaya anak yang diruwat tidak menjadi mangsa barongan. Dalam hajatan seperti upacara perkawinan dan khitanan, bahkan peringatan hari-hari besar nasional pun kesenian Barongan juga sering dipentaskan sebagai pemenuhan kebutuhan hiburan. Hal ini menandakan bahwa Barongan pada jaman itu digemari masyarakat, terutama masyarakat pedesaan, mulai dari anak-anak, remaja sampai orang tua. Mereka dengan antusias mengikuti acara dengan cara berjalan mengelilingi desa atau mengerumuni pertunjukan kesenian Barongan.

Kondisi di atas amatlah berbeda dengan masa sekarang, kesenian tradisional Barongan tidak lagi menjadi pertunjukan yang istimewa bagi masyarakatnya. Barongan tidak lagi laku digunakan untuk memeriahkan acara-acara penting seperti ruwatan, hajatan, khitanan, pernikahan, atau hari-hari besar lainnya. Kesenian Barongan kehilangan esensi sebagai fungsi ritual. Mayarakat Pati hanya menjadi Barongan sebagai kesenian yang bersifat hiburan semata bahkan tidak sedikit kelompok seni tersebut yang menggunakannya untuk mengamen. Jika dahulu penyajian atraksi kesenian itu masih diisi tokoh yang lengkap, kini hanya diisi tokoh utama Singo Barong. Demikian pula peralatan yang digunakan terkesan seadanya dan tak terpelihara baik secara budaya. Alhasil, kesenian tradisional Kabupaten Pati miskin peminat dan regenerasi untuk melanjutkan. Oleh masyarakatnya, Kesenian Barongan dipandang sebagai kesenian kuno yang ketinggalan zaman dan mereka cenderung memilih budaya populer yang lebih modern.

\section{Kesenian Barongan dalam Pergeseran Budaya}

Kesenian modern yang muncul belakangan menyebabkan kesenian tradisional semakin tergerus oleh budaya zaman. Kesenian tradisional makin sulit ditemukan di kota-kota. 
Kondisi krisis penonton serta penurunan frekuensi pementasan mengakibatkan banyak kelompok seni yang mengalami mati suri atau bahkan berhenti sama sekali. Faktor penting yang berperan besar dalam krisis tersebut adalah pengaruh teknologi informasi. Meningkatnya sarana dan prasarana informasi terutama teknologi elektronika, seperti radio dan televisi selain memberi pengaruh positif, ternyata juga membawa pengaruh negatif. Salah satu pengaruh negatif dari radio dan televisi adalah semakin menurunnya minat masyarakat menonton secara langsung seni pertunjukan kesenian tradisional. Masalah itu juga menjadi penyebab keberadaan kesenian tradisional yang semakin menghawatirkan. Jika animo serta minat masyarakat modern terhadap seni pertunjukan tradisional semakin menipis, maka akan semakin banyak seni tradisi yang mati atau punah.

Modernisasi berdampak pada semua aspek kehidupan, salah satunya adalah adanya pergeseran budaya. Perubahan budaya terjadi di dalam masyarakat tradisional, yakni perubahan dari masyarakat tertutup menjadi masyarakat yang lebih terbuka, dari nilai-nilai yang bersifat homogen menjadi pluralisme. Ilmu pengetahuan dan teknologi telah mengubah dunia secara mendasar. Komunikasi dan sarana transportasi internasional telah menghilangkan batas-batas budaya setiap bangsa.

Permasalahan pergeseran budaya akibat modernisasi juga berdampak pada perkembangan kesenian tradisonal Barongan. Perubahan pola hidup masyarakat yang lebih modern menjadikan mereka lebih memilih kebudayaan baru yang mungkin dinilai lebih menarik dan praktis dibandingkan dengan budaya lokal. Perkembangan teknologi informasi yang semakin canggih menawarkan banyak alternatif hiburan yang lebih beragam yang kemungkinan lebih menarik jika dibanding dengan kesenian tradisional. Kondisi ini menyebabkan makin tersisihnya kesenian tersebut dari kehidupan masyarakat pemiliknya. Dengan datangnya perubahan sosial yang hadir sebagai akibat proses industrialisasi dan sistem ekonomi pasar serta globalisasi informasi maka kesenian tradisional ini pun mulai bergeser ke arah kesenian yang berdimensi komersial. Kesenian tradisional tidak lagi digunakan sebagai alat ritual, dan pendidikan. Kesenian yang awalnya sakral kini menjadi lebih banyak bersifat hiburan. Kesenian tradisional mulai tersingkir dan kehilangan fungsinya. Hal ini sangat disayangkan mengingat Barongan merupakan kesenian tradisional yang sarat akan pesan moral.

Kesenian tradisional Barongan mengalami krisis eksistensi. Sepinya penikmat serta manajemen yang tidak tertata rapi sempat membuat kesenian ini menjadi pasang 
surut. Terjadinya mobilitas lapangan kerja dari petani dan pelaku kesenian tradisional ke profesi lainnya menggeser nila-nilai masyarakat yang ada. Pergeseran nilai dari agraris ke industri memberikan dampak positif dan negatif bagi masyarakat tersebut. Masyarakat industri cenderung konsumeristis, status sosial seseorang dalam masyarakat bukan lagi diukur dari kepemilikan sawah yang luas atau jumlah kerbau yang banyak, tetapi sudah berganti dengan berbagai barang elektronika atau mekanik, seperti: radio, televisi, motor, mobil, dan lain-lain. Mudahnya menikmati berbagai hiburan yang disajikan oleh media elektronika, menyebabkan mereka enggan untuk bersusah payah mengeluarkan biaya, waktu dan tenaga mencari hiburan di luar rumah. Terlebih lagi, hiburan yang disajikan oleh media elektronika tersebut selain memiliki variasi banyak, juga memiliki pesona yang banyak pula.

Selain itu, minat masyarakat terutama remaja dan pemuda di Kabupaten Pati terhadap kesenian Barongan masih sangat minim, mereka lebih menyukai bahkan meniru kebudayan luar. Adanya fasilitas seperti radio, televisi, internet, majalah yang banyak menampilkan kebudayaan asing membuat para pemuda dan remaja ini tidak dapat membendung keingintahuan mereka untuk mencoba dan meniru. Akhirnya, kesenian lokal mereka anggap sebagai hal yang kuno dan ketinggalan zaman, sementara kebudayaan asing mereka nilai lebih maju dan modern. Kesadaran masyarakat Pati untuk menjaga budaya lokalnya sekarang ini masih terbilang minim. Mereka cenderung memilih budaya asing yang lebih praktis dan sesuai dengan perkembangan zaman meskipun beberapa di antara budaya asing tersebut yang tidak sesuai dengan kepribadian bangsa.

Para pelaku kesenian Barongan tergolong kurang kreatif dan inovatif. Banyak anggapan yang menyatakan bahwa kesenian tersebut tidak menghibur jika dibandingkan dengan kesenian yang disiarkan melalui televisi, yang sebagian besar adalah kesenian modern. Jika kondisi tersebut tidak diimbangi dengan kreatifitas para pelaku kesenian dalam rangka melakukan adaptasi terhadap perkembangan zaman, maka pelan-pelan kesenian tersebut akan kehilangan pengikut atau penikmat. Eksistensinya sebagai media hiburan akan hilang, posisinya akan terancam punah. Mengingat kesenian Barongan adalah salah satu kesenian tradisional produk budaya yang rentan terhadap gempuran budaya asing. Sehingga di era modern seperti sekarang, untuk tetap eksis, para pelaku seni tradisi harus bisa lebih kreatif mengemas keseniannya. 
Kurangnya pemahaman pelaku seni tradisi Barongan terhadap pentingnya manajemen yang baik dalam pengelolaan administrasi juga menjadi penyebab mati surinya kelompok-kelompok kesenian tersebut. Sebagai alternatif untuk memberikan solusi atas masalah ini adalah dengan memfungsikan manajemen kesenian tradisional secara lebih efektif. Dengan harapan, bahwa kesenian tradisional harus dikelola secara profesional, dan manajemen ini dapat berfungsi untuk mengatur pentas seni tradisional tanpa harus kehilangan akar budayanya.

Kesenian tradisional Barongan yang mempunyai nilai-nilai luhur dan sarat pesan moral, kondisinya harus terus dipertahankan. Menurut Edi Sedyawati, agar kebudayaan dapat lestari, yaitu selalu dapat mempertahankan eksistensinya, maka diperlukan upayaupaya untuk menjamin keberlanjutannya antara lain dengan perlindungan, pengembangan, dan pemanfaatan. Pemanfaatan di sini meliputi upaya-upaya untuk menggunakan hasil-hasil budaya guna berbagai keperluan, seperti untuk menguatkan citra identitas daerah, untuk pendidikan kesadaran budaya, untuk dijadikan muatan industri budaya, dan untuk dijadikan sebagai daya tarik wisata. Dengan demikian, pemanfaatan hasil-hasil budaya melalui pembangunan pariwisata merupakan salah satu langkah untuk menjaga agar kebudayaan dan hasil-hasilnya dapat lestari (2006: 76).

Pelestarian kesenian tradisional harus dilakukan terutama oleh masyarakat pemiliknya sendiri. Peran masyarakat Pati terhadap kepedulian kebudayaannya harus total. Mereka harus peduli terhadap nasib kesenian Barongan yang hampir punah. Kepedulian itu baiknya juga dibarengi dengan sebuah aksi guna melestarikan dan menjaga kekayaan budaya yang memang sudah sepatutnya dilakukan oleh segenap bangsa Indonesia. Masyarakat harusnya mencoba mengembangkan kesenian tradisional menjadi bagian dari kehidupan modern, berupaya memodifikasi bentuk-bentuk seni yang masih berpolakan masa lalu untuk dijadikan komoditi yang dapat dikonsumsi masyarakat modern. Karena kesenian Barongan yang dimiliki masyarakat Pati merupakan salah satu budaya lokal milik Indonesia yang mewakili identitas bangsa. Untuk itu, kesadaran melestarikan dan menjaga Kesenian tradisional dari dampak pergeseran budaya tetap harus dilakukan. Pembelajaran tentang budaya harus ditanamkan sejak dini. Karena melalui pembelajaran budaya, masyarakat dapat mengetahui pentingnya budaya lokal dalam membangun budaya bangsa yang berkepribadian. 
Selain itu, optimalisasi peran lembaga kebudayaan perlu ditingkatkan. Lembagalembaga kebudayaan baik berupa lembaga swadaya masyarakat (LSM), sanggar, atau paguyuban merupakan elemen lain yang dapat berperan serta dalam pelestarian kesenian tradisional. Sejauh ini lembaga kebudayaan dipandang sebagai elemen masyarakat yang relatif memiliki perhatian dan kepedulian terhadap eksistensi dan kelangsungan kesenian tradisional. Optimalisasi peran lembaga kebudayaan memerlukan dukungan pemerintah. Pemerintah berkewajiban memberikan dorongan dan ekpresi yang cukup demi kelangsungan seni tradisional Barongan. Partisipasi pemerintah dapat berupa penyuluhan, pembinaan dan pelatihan bagi kelompok kesenian tradisional Barongan yang bertujuan untuk memberikan arah dalam pengembangan. Pemerintah juga perlu memberikan intensif atau apapun namanya kepada lembaga kebudayaan yang memiliki komitmen, konsisten, dan secara kontinyu melakukan kegiatan-kegiatan pelestarian tradisional. Pemerintah Provinsi Jawa Tengah maupun Pemerintah Kabupaten Pati bertanggung jawab akan hal ini.

\section{Simpulan}

Dalam uraian pendahuluan dapat dipahami bahwa kesenian tradisional Barongan yang berkembang di Kabupaten Pati Jawa Tengah awalnya memiliki fungsi ritual. Pada perkembangan berikutnya, terutama pada masyarakat modern, pementasan kesenian tradisional bergeser fungsinya hanya sekedar sebagai hiburan semata. Eksistensi kesenian Barongan sebagai seni dan budaya tradisional di Indonesia semakin lama semakin tergerus oleh ekspansi seni dan budaya global. Jika hal ini terus berlangsung, maka masyarakat, khususnya masyarakat Pati semakin tidak apresiatif terhadap kesenian daerahnya sendiri. Mereka pada gilirannya nanti akan menjadi terasing dari seni dan budaya tradisional warisan leluhurnya. Dampak terburuknya, masyarakat ini akan berangsur kehilangan jati diri. Oleh karena itu, berbagai upaya harus dilakukan untuk melestarikan seni dan budaya daerah di tengah-tengah perubahan zaman dan pengaruh budaya asing yang semakin gencar di Indonesia.

\section{Daftar Pustaka}

Bandem, I Made. 2001. "Potensi Budaya Bangsa dalam Koridor Produk Wisata Berbasis Alam dan Budaya di Negara-negara Asean". Makalah Dipresentasikan dalam Tourism, Culture, and Art Forum di Melia Purosani Hotel, Semarang, 7 Desember. 
Brandon, James R. 1970. The Theatre in Southeast Asia. Cambridge, Massachusset: Harvard University Press.

Koentjaraningrat. 1994. Kebudayaan Jawa. Jakarta: Balai Pustaka.

Martini, Laura Andri. 2007. "Manajemen Seni Pertunjukan Tradisional di Semarang (Wayang Orang Ngesti Pandowo, Suko Raras dan Sobokarti)". Penelitian Dosen Muda Fakultas Ilmu Budaya Undip.

Studi Kasus Kesenian Menak Koncer Sumowono Semarang”, dalam Humanika Vol. 24 no. 2.

Permas, Achsan, dkk. 2003. Manajemen Organisasi Seni Pertunjukan. Jakarta: PPM.

Sadiyah, Siti. 2011. Wayang Orang Ngesti Pandowo Bagi Penonton. (Penelitian)

Sedyawati Edi. 2006. Budaya Indonesia: Kajian Arkeologi, Seni dan Sejarah. Jakarta: RajaGrafindo Persada.

Sepiolita, Ria Twin. 2014. "Bentuk Struktur dan Cara Penyajian Barongan di Kecamatan Gabus Kabupaten Pati”, Prosiding Seminar Nasional Evaluasi Pendidikan Unnes.

Soedarsono (A). 1986. "Dampak Modernisasi Terhadap Seni Pertunjukkan Jawa di Pedesaan." Proyek Penelitian dan Pengkajian Kebudayaan Nusantara (Javanologi), Yogyakarta. 